\title{
Seasonal dynamics of bacterial biomass and production on eelgrass Zostera marina leaves
}

\author{
Erik Törnblom *, Morten Søndergaard
}

Freshwater Biological Laboratory, University of Copenhagen, Helsingørsgade 51, DK-3400 Hillerød, Denmark

\begin{abstract}
The seasonal dynamics and distribution of bacteria and bacterial activity on eelgrass leaves were followed at a shallow-water site in the Roskilde Fjord, Denmark. Eelgrass leaves were sites of highly active bacterial communities exhibiting distinct distribution patterns with increasing bacterial abundance and production with increasing leaf age and from base to tip of individual leaves. High bacterial production and very high specific growth rates (seasonal mean $0.30 \mathrm{~h}^{-1}$ ) suggest a strong coupling between attached bacterial communities and plant primary production. Incorporation rates of ${ }^{14} \mathrm{C}$-leucine and ${ }^{3} \mathrm{H}$-thymidine were significantly correlated but the ratio between bacterial production based on leucine and thymidine increased with increasing leaf age and from leaf base to leaf tip, indicating a higher protein synthesis compared to DNA synthesis with increasing biofilm age. Bacterial biomass production was very high compared to the standing stock of bacteria and it was concluded that close to $100 \%$ of the bacterial biomass produced on the leaves was lost on a daily basis. Moreover, bacterial specific growth rates corresponded to turnover times of 1 to a few hours on most occasions and did not differ between leaves of different ages or at different locations on the leaves. Such high growth rates can only occur in a very rich environment, where the standing stock of biomass is kept low and thus prevents resource competition.
\end{abstract}

KEY WORDS: Biofilm · Bacteria $\cdot$ Abundance Production · Eelgrass · Zostera marina

\section{INTRODUCTION}

Bacterial growth on particles has often been considered insignificant in oceans since the abundance and production of free-living bacteria usually are several times higher than those of attached bacteria (Ducklow \& Carlson 1992, Kirchman 1993). In more shallow aquatic environments, like estuaries and lakes, the proportion of attached cells is normally much larger (Kirchman \& Ducklow 1987) and may contribute significantly to the total bacterial activity. Seagrasses and their associated epiphytic algal communities dominate the primary production in many shallow coastal environments. In Danish coastal waters, eelgrass Zostera marina L. forms beds extending from mean low water level to depths between 2 and $14 \mathrm{~m}$ (Wium-Andersen \& Borum 1984). These seagrass stands provide a large

\footnotetext{
- Present address: Institute of Limnology, Uppsala University, Norbyv. 20, SE-752 36 Uppsala, Sweden.

E-mail: erik.tornblom@limno.uu.se
}

surface area for algal and bacterial colonization and growth. For example, the average leaf area index (leaf area per $\mathrm{m}^{2}$ ) in our study area is 3.2 but may in Danish waters be as high as 13.5 at maximum development of eelgrass (Borum et al. 1990). Comparatively little is known about the distribution and activity of epiphytic bacteria on aquatic plants but the available information indicates high bacterial abundances (Newell 1981, Novak 1984) and productivity (Kirchman et al. 1984, Blum et al. 1988). Bacterial communities attached to seagrasses have proved to be able to obtain both organic carbon, phosphorus and nitrogenous compounds directly from the leaves (Harlin 1980, Penhale \& Thayer 1980). Moreover, Kirchman et al. (1984) showed that almost the entire carbon demand of a bacterial community attached to eelgrass could be fulfilled by carbon exudated by the plant. Altogether, it appears as if the bacterial communities attached to eelgrass leaves are microbial hot spots with high abundances, high activity per volume and rapid turnover times. 
Eelgrass grows by a continuous formation of new leaves elongating from the base and thus contributes substantially to the carbon turnover in coastal areas with extensive seagrass beds. This growth pattern enables the determination of leaf age and the age of different parts of the leaf, facilitating studies of epiphyte colonization and growth (Wium-Andersen \& Borum 1984). The present study was performed over 11 mo at a shallow site in Roskilde Fjord, Denmark. Its purpose was to quantify the distribution and activity of bacteria on eelgrass leaves of different ages at a seasonal scale and such results are presented for the first time.

\section{METHODS}

Study site and sampling. The study was conducted in a smail (ca $20 \mathrm{~m}^{2}$ ) eelgrass Zostera marina L. meadow at a shallow site $(0.4$ to $1.0 \mathrm{~m})$ in the Roskilde Fjord, Denmark (55 $\left.55^{\prime} \mathrm{N}, 12^{\circ} 01^{\prime} 40 \mathrm{E}\right)$. The salinity at the sampling site varies annually between 16 and $20 \%$ (Anonymous 1995). The sampling site is characterized by a mixture of unvegetated sandy sediments and eelgrass meadows extending from mean low water level down to a depth of several meters.

Bacterial biomass and production associated with eelgrass leaves were monitored on 14 occasions between April 1996 and March 1997. At each sampling, water depth and temperature were recorded. At least 10 intact shoots were collected, placed in sea water and transported to the laboratory. In the laboratory, the average number and length of leaves were determined on 10 plants. A shoot with a size as close as possible to the mean was selected for further analyses. The relative age of each leaf was determined from order of emergence in comparison with the other leaves on the plant. The approximate age of each leaf used for the estimation of losses of bacteria between different sampling occasions was calculated using the relative leaf age and data on eelgrass growth based on plastochrone intervals (leaf emergence) of eelgrass in Danish waters (Wium-Andersen \& Borum 1984).

Bacterial biomass and biomass production on leaf tips were followed over time by estimating the position of each leaf on the following sampling occasions. In order to separate bacterial abundance and activity on leaves of different ages and biofilm development, the leaves were cut at the base, starting with the oldest leaves and then with decreasing age. The width of each leaf was measured at the tip, at the mid and at the base. Two or three Jeaf segments $(1.0 \mathrm{~cm})$ were cut from the tip $(1.0 \mathrm{~cm}$ below the tip), from the middle and from the base using parallel mounted razor blades. Each segment was placed twice in excess sterile-filtered $10.22 \mu \mathrm{m}$ filtered, Milli- pore) sea water for between 5 and 10 min to equilibrate before analyses. On 2 occasions, the sampling program was extended to 3 replicate plants in order to evaluate the variation between plants.

Bacterial abundance and biomass. Bacterial abundance was determined on glutaraldehyde preserved samples by standard epifluorescence microscopy after DAPI staining (final concentration $0.1 \mathrm{mg} \mathrm{l}^{-1}$ ) according to Porter \& Feig (1980). The leaf segments $1.0 \mathrm{~cm}$ cuts) from each leaf were placed in $5 \mathrm{ml}$ sterile-filtered (0.22 $\mu \mathrm{m}$ Millipore filters) sea water and preserved (final concentration $1.2 \%$ ). Before DAPI staining, the plant segments were sonicated for $4 \mathrm{~min}$ (50\% duty cycle) at $30 \mathrm{~W}$ (Branson Sonifier 250, $306 \mu \mathrm{m}$ amplitude) in order to separate the bacteria from the plant surface. The procedure was tested before application (bacteria on leaves and in suspension after sonication were enumerated microscopically after staining with DAPI) and showed more than 95\% separation. At least 500 bacterial cells were counted from each sample. Average bacterial biovolumes were calculated from enlarged micrographs after measurements of length and width of at least 50 cells. Biovolumes for cocci and rods were calculated as spheres and cylinders with hemispherical ends, respectively. Bacterial biomass was calculated from abundance and average population biovolume, assuming a carbon content of $100 \mathrm{fg}$ $\mu \mathrm{m}^{-3}$ (Theil-Nielsen \& Sondergaard 1998). On a few occasions, fresh and intact leaf segments and crosssection cuts were stained with DAPI and studied microscopically in order to gain information on the spatial distribution on the leaves and within the biofilm.

Bacterial production. Bacterial production was estimated using a dual label technique measuring the simultaneous incorporation of ${ }^{3} \mathrm{H}$-thymidine into DNA (Fuhrman \& Azam 1980) and ${ }^{14} \mathrm{C}$-leucine into proteins applying ice-cold TCA extraction (Kirchman 1993). The method was first tested on natural water from a lake. Incubations with both single and dual label of ${ }^{3} \mathrm{H}$-thymidine and ${ }^{14} \mathrm{C}$-leucine showed no significant differences between the single and dual label methods regarding the incorporation of thymidine and leucine. We concluded that the method was operational for our purpose.

Experiments were performed in order to determine the saturating concentrations of thymidine and leucine. Final concentrations ranged between 25 and $400 \mathrm{nM}$ for thymidine and between 25 and $1600 \mathrm{nM}$ for leucine. Incubations were performed in triplicates on leaf segments from 4 leaves of different ages and with additional TCA-killed blanks.

Bacterial production was routinely measured on $1.0 \mathrm{~cm}$ leaf segments in $5 \mathrm{ml} 0.22 \mu \mathrm{m}$ filtered (Millipore) water after the addition of $25 \mu \mathrm{l}$ methyl ${ }^{3} \mathrm{H}$-thymidine (Amersham) $\left(0.98 \mathrm{Ci} \mathrm{mmol}^{-1}\right)$ and $25 \mu \mathrm{l}^{14} \mathrm{C}$-leucine (Amersham) (34 to $41 \mathrm{mCi} \mathrm{mmol}{ }^{-1}$ ). Final concentra- 
tions of thymidine and leucine were 100 and $800 \mathrm{nM}$, respectively, chosen from the saturation experiments. Samples were incubated between 30 and $60 \mathrm{~min}$ depending on water temperature $(60 \mathrm{~min}$ at temperatures lower than $10^{\circ} \mathrm{C}, 45 \mathrm{~min}$ between 10 and $15^{\circ} \mathrm{C}$ and 30 min at temperatures above $15^{\circ} \mathrm{C}$ ) under slow shaking at in situ temperature. Incubations were terminated by adding $0.25 \mathrm{ml} 100 \% \mathrm{TCA}$. The bacteria were separated from the leaf segments by sonication at $30 \mathrm{~W}$ (Branson Sonifier 250, $306 \mu \mathrm{m}$ amplitude) for $4 \mathrm{~min}$ ( $50 \%$ duty cycle), cooled, and collected on $0.4 \mu \mathrm{m}$ cellulose-nitrate filters (Micro Filtration System). The filters were rinsed 4 times with 5\% TCA and twice with $80 \%$ ethanol. Radioactivity of the removed bacteria and the plant segments was quantified separately with an LKB Wallac 1219 Rackbeta liquid scintillation counter. In the production calculations we used the sum of the activity of the removed bacteria and the activity of the leaf segments after sonication. Typically, the activity of the leaf segments was between 0 and $15 \%$ of that of the separated bacteria.

Bacterial cell production was estimated from thymidine incorporation rates using the conversion factor $2.0 \times 10^{18}$ cells $\mathrm{mol}^{-1}$ thymidine (Fuhrman \& Azam 1980). Leucine incorporation rates were converted into carbon units using the factor $3.1 \mathrm{~kg} \mathrm{C} \mathrm{mol}{ }^{-1}$ incorporated leucine (Simon \& Azam 1989). Specific growth rates were calculated from cell production and abundance, and assuming exponential growth.

\section{RESULTS}

\section{Saturation experiments}

The saturation experiments showed that thymidine incorporation was saturated at concentrations well below the $100 \mathrm{nM}$ applied in the field study (Fig. 1A). No increase in thymidine incorporation was found at final thymidine concentrations of up to $400 \mathrm{nM}$. Leucine incorporation rates approached saturation at about $400 \mathrm{nM}$ and no further uptake was found at higher concentrations (up to $1600 \mathrm{nM}$ ) (Fig. 1B). Leucine saturation curves fitted to the MichaelisMenten equation, yielding $\mathrm{r}^{2}$ values between 0.36 and 0.91 for the different leaves. Estimates of $K_{\mathrm{m}}$ varied between 55 and 224 nM which corresponded to between 78 and $94 \%$ saturation at the $800 \mathrm{nM}$ used in the seasonal study.

\section{Distribution of bacteria and bacterial biomass}

Microscopic studies of DAPI-stained leaf surfaces and cross-sections of leaf segments revealed that the
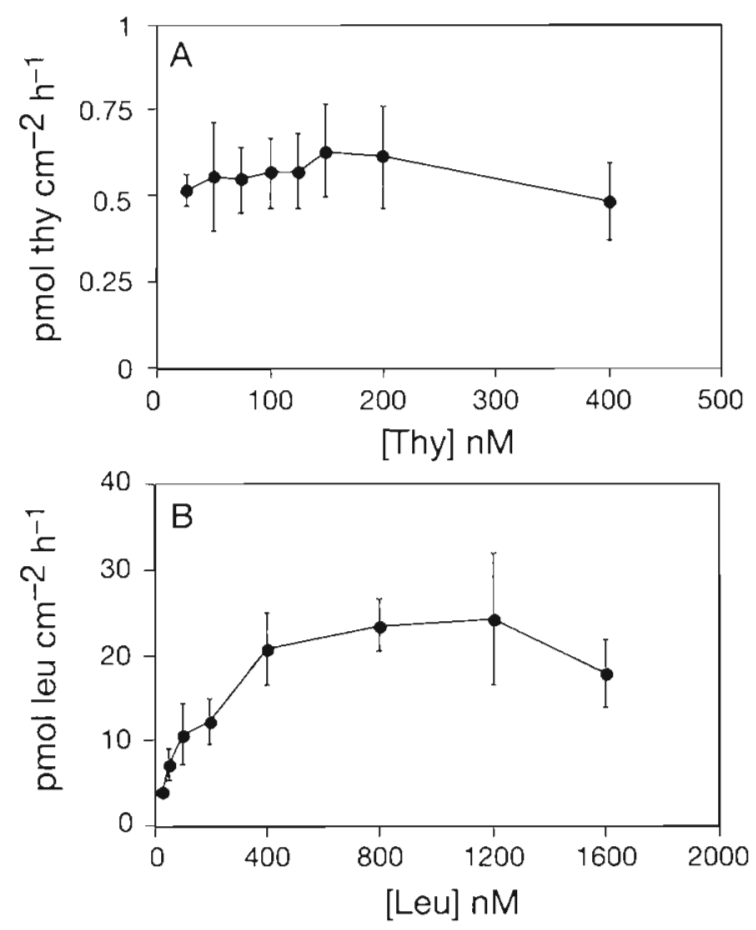

Fig. 1. Saturation curves for the incorporation of $(A){ }^{3} \mathrm{H}$-thymidine and (B) ${ }^{14} \mathrm{C}$-leucine of bacterial communities attached to Zostera marina leaves. Values are means of 4 experiments performed with leaves of variable age. Error bars denote \pm SE

bacteria closest to the leaf surface formed a layer of large uniform-sized rods, densely packed together with one end attached to the plant and the other end facing the surroundings (Fig. 2A). On older leaves, this bacterial bottom layer of standing rods was covered with a thick and heterogeneous mucous layer where the bacteria appeared to be more randomly distributed in space (Fig. 2B). The size and shapes of bacteria in these overlying layers varied largely, including cocci, rods and filaments. With increasing leaf age, an increasing number of the diatom genus Cocconeis was embedded in the biofilm. No bacteria were found on the surfaces of living diatoms. Especially on older leaves, microflagellates were often observed within the biofilm, but no quantification was made.

The bacterial abundance ranged from a minimum of $2 \times 10^{5}$ cells $\mathrm{cm}^{-2}$ on leaf bases of new leaves in late June to a maximum of $4.0 \times 10^{7}$ cells $\mathrm{cm}^{-2}$ on tips of old leaves in late May. The lowest bacterial abundances were always found on new leaves and ranged between $1.7 \times 10^{5}$ and $2.18 \times 10^{7}$ cells $\mathrm{cm}^{-2}$. Abundances then increased stepwise with increasing leaf age and exposure time, independent of season. On average, bacterial abundance increased by a factor of 3.2 from the newest to the oldest leaf (Fig. 3A). Bacterial abundance was high on all leaves during winter and autumn (Fig. 4A), periods of low leaf turnover and long expo- 

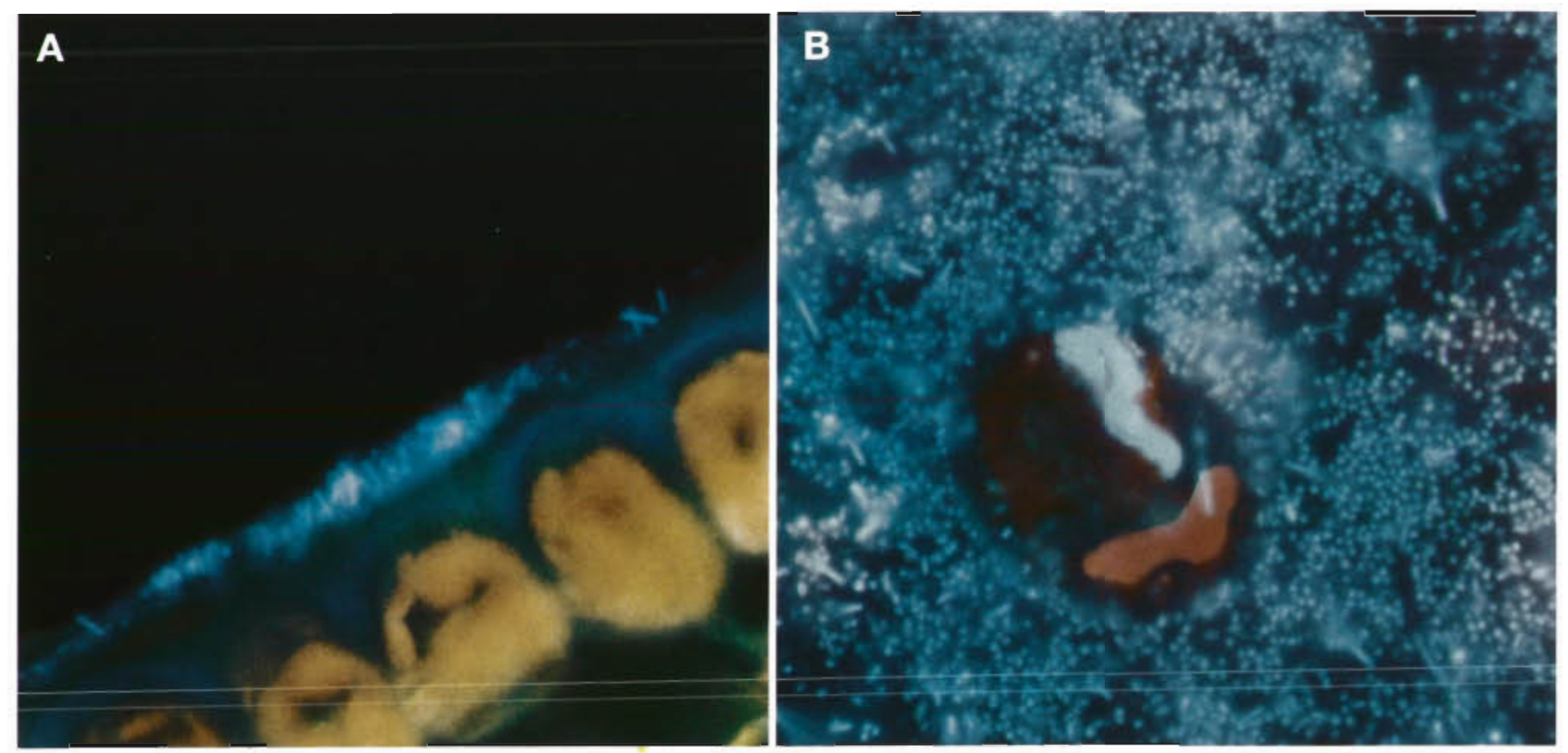

Fig. 2. Epifluorescent micrographs of DAPI-stained eelgrass Zostera marina leaves showing (A) the distribution of bacteria on the leaf surface (cross-section cut) and (B) a more mature biofilm on the surface of an old leaf $(1 \mathrm{~cm}=10 \mu \mathrm{m})$. See 'Results' for a more detailed description

sure times. The most pronounced differences between leaves of different ages were found in May and mid June. Generally, bacterial abundances were low on all leaf ages during the highest leaf turnover in May to mid August with the exception of the oldest leaves in

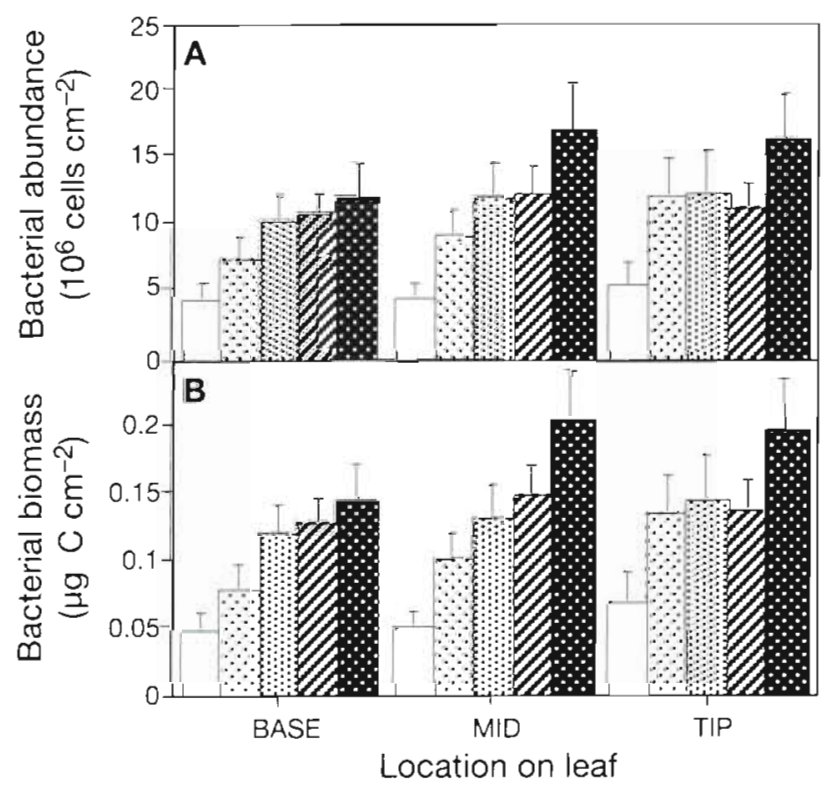

Fig. 3. Seasonal means of (A) bacterial abundance and (B) bacterial biomass on different locations (leaf bases, mids and tips) on eelgrass leaves with increasing age from left to right. Error bars denote $\pm \mathrm{SE}, \mathrm{n}=11$ to 1.4 late May and early June. In mid August abundances exhibited a marked 4 - to 7 -fold increase on all leaves.

Mean bacterial cell volumes ranged between 0.07 and $0.20 \mu^{3}$ over the season but no systematic differences were found, neither with respect to position on the leaves nor between leaves of different age. Changes in bacterial biomass were accordingly fully controlled by abundance (Fig. 4).

\section{Bacterial production}

The rates of incorporation of ${ }^{14} \mathrm{C}$-leucine and ${ }^{3} \mathrm{H}$ thymidine were significantly correlated $\left(\mathrm{r}^{2}=0.63, \mathrm{n}=\right.$ 201, $\mathrm{p}<0.0001$ ). On a molar basis, the average leucine:thymidine incorporation ratio was 50.7 . When transformed into carbon units, leucine incorporation yielded on average 5.9 times higher values than thymidine incorporation. The leucine:thymidine production ratio increased linearly with increasing leaf age from approximately 4 on new leaves to 8 on the oldest leaves and from leaf base to leaf tip by a factor of 1.8 (Table 1, Fig. 5). The estimates of bacterial production from leucine incorporation differed between leaves of different age and increased on average by a factor of 7.7 from the newest to the oldest leaf (Table 1, Fig. 5).

Bacterial production also differed significantly between location on each leaf with an average production 1.3 times higher on leaf tips compared with leaf bases (Table 1). Production based on thymidine incor- 
Fig. 4. Seasonal variation of (A) bacterial abundance and $(B)$ bacterial biomass on eelgrass leaves. Values are means expressed per $\mathrm{cm}^{2}$ of whole leaf based on measurements on tips, mids and bases of leaves and shown with increasing relative leaf age from left to right (open bars: newest leaves; filled black bars: oldest)

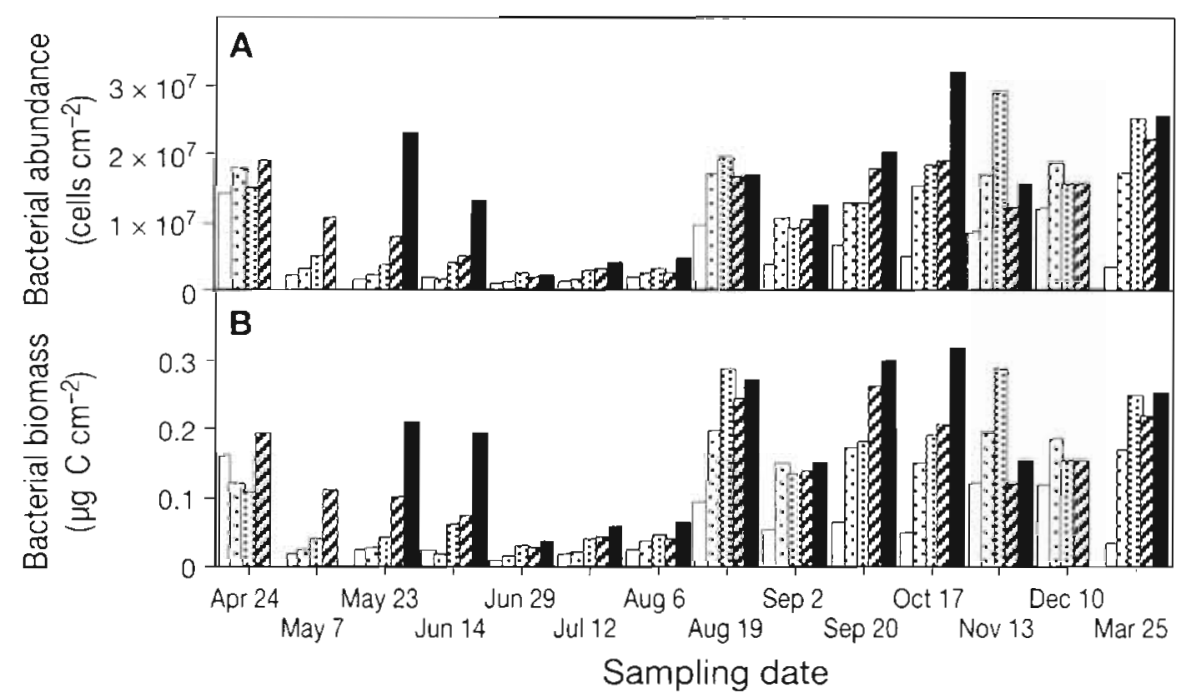

poration rates exhibited a similar pattern with a significant difference between leaves of different ages (Table 1, Fig. 5), increasing by a factor of 4.6 from newly emerged leaves to the oldest leaves. No significant differences in bacterial production based on thymidine incorporation, however, were found between the different positions on the leaves (Table 1).

Bacterial specific growth rates $(\mu)$ differed between sampling occasions (Table 1) and ranged between a minimum of $0.01 \mathrm{~h}^{-1}$ in March and a maximum of $0.83 \mathrm{~h}^{-1}$ in mid July. The seasonal mean was $0.30 \mathrm{~h}^{-1}$ (Fig. 6). In contrast to bacterial biomass and production no significant differences in specific growth rates were found between leaves of different ages or between position on leaves for the entire dataset (Table 1). When calculated on a whole leaf basis, however, a more variable seasonal pattern emerged with marked differences between leaf ages during specific periods or sampling occasions (Fig. 6). In late May and mid June, during the period of low production, the cell-specific bacterial activity was high showing that the few bacteria were very active. During this period, bacterial specific growth rates were highest on new leaves and decreased stepwise by approximately a factor of 5 from the newest to the oldest leaf. In July and early August bacterial specific growth rates were very high on all leaves. This period was followed by lower specific activity in late August and early September and increasing growth rates with increasing leaf age. From November to March, bacterial specific growth rates were low on all leaves.

The average bacterial production per leaf largely followed the seasonal changes in water temperature (Fig. 6). Bacterial production estimated from leucine incorporation rates exhibited pronounced seasonal dynamics and varied between a minimum of $0.28 \mathrm{ng} \mathrm{C}$ $\mathrm{cm}^{-2} \mathrm{~h}^{-1}$ on new leaves with a low abundance in June

Table 1. Analysis of variance (ANOVA) for the effects of sampling date, leaf age and location on bacterial production from leucine and thymidine incorporation rates, the leucine/thymidine incorporation ratio, bacterial abundance, bacterial biomass, bacterial specific growth rate and mean bacterial cell volume

\begin{tabular}{|llrcr|}
\hline Dependent variable & Source of variation & df & F-value & p-value \\
\hline Bacterial production & Date & 13 & 25.66 & $<0.0001$ \\
Leu & Leaf age & 4 & 46.85 & $<0.0001$ \\
& Location & 2 & 5.572 & 0.0045 \\
Bacterial production & Date & 13 & 22.50 & $<0.0001$ \\
Thy & Leaf age & 4 & 27.18 & $<0.0001$ \\
& Location & 2 & 0.687 & 0.5042 \\
Leu/Thy ratio & Date & 13 & 9.913 & $<0.0001$ \\
& Leaf age & 4 & 8.268 & $<0.0001$ \\
& Location & 2 & 4.62 & 0.0110 \\
Bacterial abundance & Date & 13 & 46.97 & $<0.0001$ \\
& Leaf age & 4 & 46.33 & $<0.0001$ \\
Bacterial biomass & Location & 2 & 2.469 & 0.0875 \\
& Date & 13 & 33.46 & $<0.0001$ \\
& Leaf age & 4 & 45.98 & $<0.0001$ \\
Specific growth rate & Location & 2 & 3.144 & 0.0455 \\
& Date & 13 & 33.5 & $<0.0001$ \\
& Leaf age & 4 & 0.406 & 0.8043 \\
Mean cell volume & Location & 2 & 0.567 & 0.5683 \\
& Date & 13 & 26.66 & $<0.0001$ \\
& Leaf age & 4 & 1.701 & 0.1516 \\
& Location & 2 & 0.792 & 0.4545 \\
& & & & \\
\hline
\end{tabular}




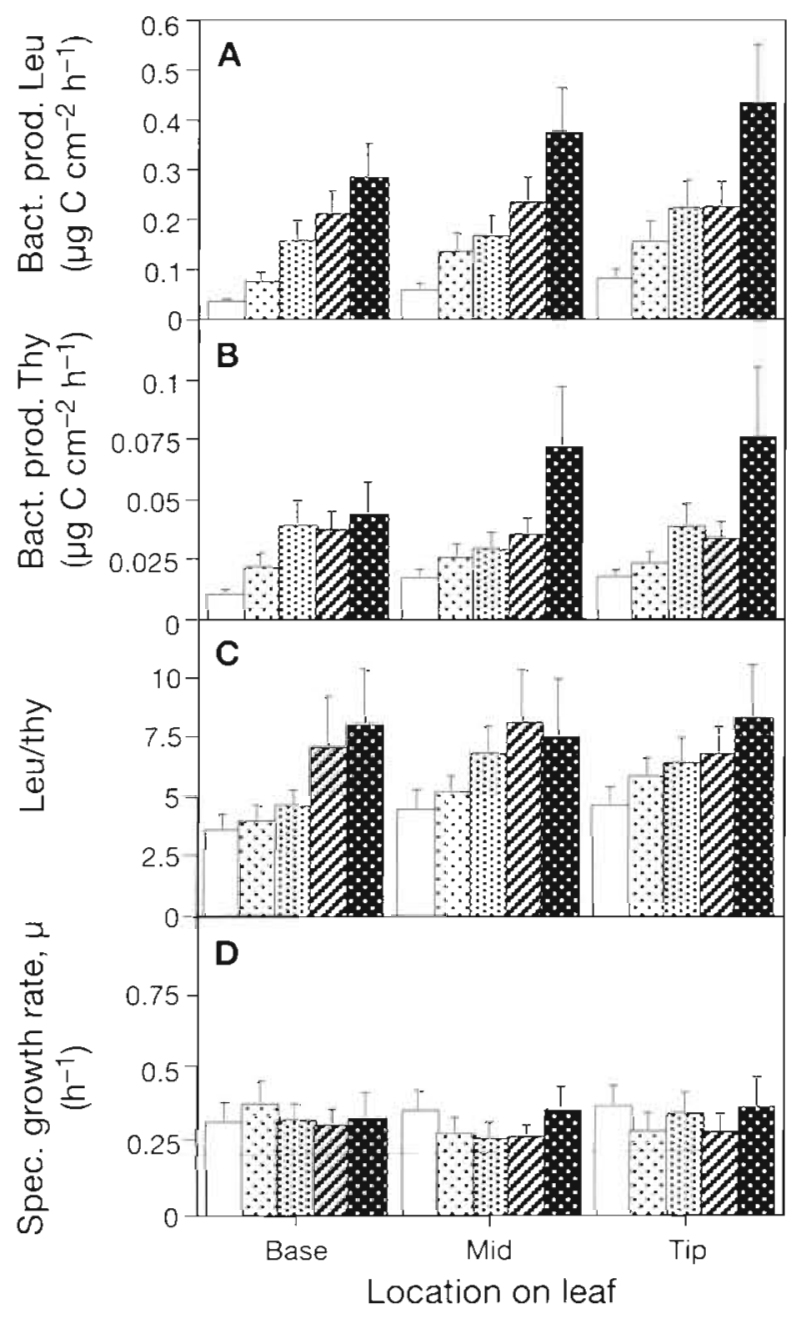

Fig. 5. Seasonal means of (A) bacterial production from leucine incorporation, (B) bacterial production from thymidine incorporation, $(\mathrm{C})$ the ratio between bacterial production based on leucine incorporation and thymidine incorporation and (D) bacterial specific growth rates on different locations (leaf bases, mids and tips) on eelgrass leaves with increasing age from left to right. Error bars denote $\pm \mathrm{SE}, \mathrm{n}=11$ to 14

1996 and a maximum close to $1 \mu \mathrm{g} \mathrm{C} \mathrm{cm}^{-2} \mathrm{~h}^{-1}$ on old leaves in late August 1996 (Fig. 6). Bacterial production was comparatively high in late April and almost reached $0.4 \mu \mathrm{g} \mathrm{C} \mathrm{cm}^{-2} \mathrm{~h}^{-1}$ on the oldest leaves. During the following sampling occasions, bacterial production decreased to a minimum in mid June in spite of increasing water temperatures and the high abundances observed on old leaves in May and June did not result in high bacterial production. High bacterial production was found from the end of June to late September with a peak in mid August coinciding with the seasonal maximum in water temperature. Bacterial production decreased in October and reached a low winter level in November.
Estimates of losses of bacterial production between sampling occasions, based on leaf removal rates and changes in bacterial biomass and cell production (from thymidine incorporation rates) on leaf tips, varied from $99.1 \%$ in August to $103.5 \%$ in late April-early May with a seasonal mean of $100.1 \%$ (Table 2 ). The estimated mean daily loss was $99.8 \%$ during the 11 mo period studied.

\section{DISCUSSION}

The most noticeable results of this study are the distinct distribution patterns of the attached bacteria and their activity, the high cell-specific bacterial growth rates and the rapid disappearance of the bacterial biomass produced, altogether indicating a rapid and important transfer of organic matter via bacteria to higher trophic ievels, and a close balance between production and elimination/losses of bacterial biomass. The bacterial specific growth rates found correspond to doubling times between $1 \mathrm{~h}$ and a few days, and a general fast turnover of the bacterial community. On most sampling occasions bacterial specific growth rates were of the same order as pure cultures in exponential growth (Brock et al. 1994) and similar to the maximum doubling time of $1.5 \mathrm{~h}$ of eelgrass-associated bacteria found by Kirchman et al. (1984) with a conversion factor for thymidine incorporation about 2 times higher than the one used here.

The level of bacterial biomass is linked to substrate supply (Billen et al. 1988) and a result of the balance between cell production and loss. With the measured perfect balance between growth and loss, there is no accumulation of biomass, and thus the quantity and quality of substrates provide an optimal growth environment, which at equal temperatures surpassed bacterioplankton by 10 -fold (Morris \& Lewis 1992). The high rates of bacterial production found are also supported by the fact that bacterial production generally is thought to be directly related to the supply of easily decomposable organic matter. Dissolved organic carbon is continuously excreted or leached from growing aquatic plants (Wetzel \& Manny 1972) and the carbon used in bacterial biomass production can be a large proportion of eelgrass production (Kirchman et al. 1984). The supply of substrate can be from several sources, including the leaf, epiphytic primary producers, and recycling Kirchman et al. (1984), however, found that the carbon used in bacterial biomass production can be a large proportion of eelgrass production which gives credit to the suggestion that the plant itself is the main carbon source. The high $\mu$ suggests that the bacteria live in an optimal environment with respect to substrate supply and quality. 


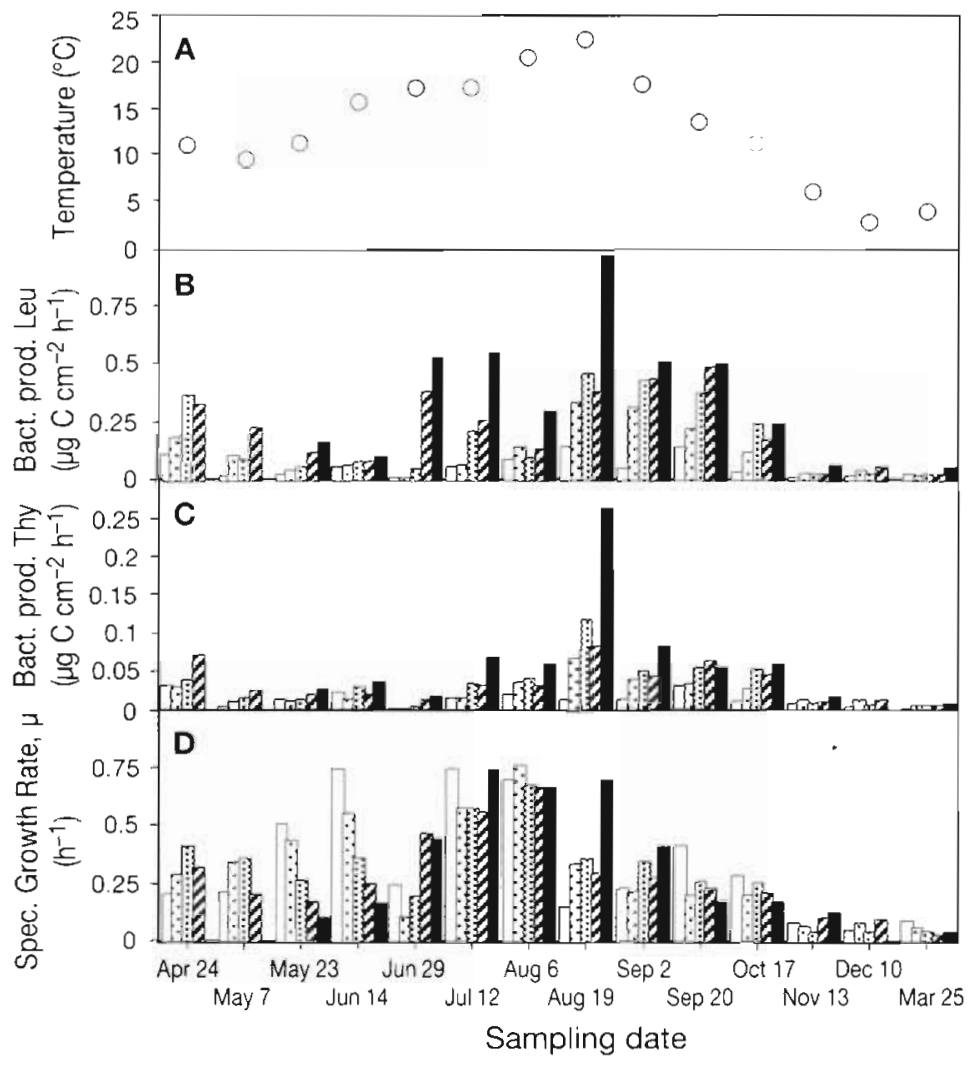

Fig. 6. Seasonal variation in (A) temperature, (B) bacterial production from leucine incorporation, $(C)$ bacterial production from thymidine incorporation and (D) bacterial specific growth rates on eelgrass leaves. Values are expressed per $\mathrm{cm}^{2}$ of leaf surface and are whole leaf means based on measurements on tips, mids and bases of leaves and shown with increasing relative leaf age from left to right (open bars: newest leaves; filled black bars: oldest) the interval late April to early May when the standing stock decreased. Averaged over the 11 mo study period, the estimated mean daily loss of bacterial biomass production was $99.8 \%$.

Altogether, these calculations demonstrate a close balance between very high cell production and losses during all seasons and over short time periods. Possible mechanisms causing these losses include bacterial detachment or sloughing of biofilm, grazing by micro- and macrograzers and bacterial mortality including viral infection. Detachment rates of bacteria attached to surfaces in aquatic systems can be very high (Aida et al. 1988, Ytow \& Seki 1996) and correspond to a major portion of the bacterial biomass production. The detachment of bacteria attached to the eelgrass leaves may therefore alone explain most of the losses from the leaves. High detachment rates would also suggest that detached bacteria make up an important portion of the bacterial biomass and production in the surrounding waters. Apart from detachment, grazing could explain some of the losses. Neckles et al. (1994) showed a tight correlation between numbers of attached bacteria and heterotrophic flagellates on eelgrass, suggesting that flagellates are important grazers of biofilm
In comparison with the high estimates of bacterial cell multiplication, the biomass of attached bacteria was low and increased only slowly with increasing leaf age, suggesting large losses of the biomass produced. Our bacterial production estimates, based on daytime incubations and integrated over time assuming no diurnal variation, could be somewhat overestimated if the rates of DOC excretion/leaching are higher during photosynthetic activity as shown by Moriarty \& Pollard (1982). However, even if the daily bacterial production was overestimated, the high bacterial production, the comparatively small standing stock of bacteria on the leaves, and the small changes in bacterial biomass over time directly indicate high losses of bacterial biomass. The estimated losses of the bacterial biomass produced during the intervals between sampling occasions ranged between $99.1 \%$ in August when the standing bacterial stock increased and $103.5 \%$ during
Table 2. Proportion of bacterial biomass production (BP) lost per day from eelgrass leaf tips between the different sampling occasions. Calculations are based on bacterial cell production (from thymidine incorporation rates) and changes in bacterial standing stock expressed per $\mathrm{cm}^{2}$ leaf and leaf age (calculated from leaf emergence order and data on eelgrass growth). Results are means of between 2 and 5 different leaves

\begin{tabular}{|c|c|c|c|c|}
\hline Day interval & $\begin{array}{l}\text { No. of } \\
\text { days }\end{array}$ & $\begin{array}{c}\Delta \text { biomass } \\
\left(\mu \mathrm{g} \mathrm{C} \mathrm{cm}^{-2}\right)\end{array}$ & $\begin{array}{c}\mathrm{BP}(\mathrm{TTI}) \\
\left(\mu \mathrm{g} \mathrm{C} \mathrm{cm}^{-2} \mathrm{~d}^{-1}\right)\end{array}$ & $\begin{array}{c}\text { BP lost } d^{-1} \\
(\%)\end{array}$ \\
\hline $24 \mathrm{Apr}-7 \mathrm{May}$ & 13 & -0.27850 & 7.866 & 103.54 \\
\hline 7 May-23 May & 16 & 0.00192 & 2.919 & 99.934 \\
\hline 23 May-14 Jun & 22 & 0.03964 & 8.025 & 99.506 \\
\hline 14 Jun-29 Jun & 15 & -0.00680 & 4.612 & 100.15 \\
\hline 29 Jun-12 Jul & 13 & 0.03825 & 11.39 & 99.664 \\
\hline 12 Jul-6 Aug & 25 & 0.01613 & 30.34 & 99.947 \\
\hline $6 \mathrm{Aug}-19 \mathrm{Aug}$ & 13 & 0.27275 & 29.59 & 99.078 \\
\hline 19 Aug-2 Sep & 14 & -0.06770 & 16.35 & 100.41 \\
\hline 2 Sep-20 Sep & 18, & 0.04766 & 23.76 & 99.799 \\
\hline $20 \mathrm{Sep}-17 \mathrm{Oct}$ & 26 & 0.07292 & 32.21 & 99.774 \\
\hline 17 Oct $-13 \mathrm{Nov}$ & 27 & 0.03728 & 14.93 & 99.75 \\
\hline $13 \mathrm{Nov}-10 \mathrm{Dec}$ & 28 & -0.01970 & 6.842 & 100.29 \\
\hline $10 \mathrm{Dec}-25 \mathrm{Mar}$ & 106 & 0.13349 & 20.31 & 99.343 \\
\hline \multirow[t]{3}{*}{ Total } & 336 & & & \\
\hline & & & Interval mean: & 100.09 \\
\hline & & & Seasonal mean & 99.841 \\
\hline
\end{tabular}


bacteria as has been shown in planktonic food webs (e.g. Fenchel 1982, Azam et al. 1983) and in sediments (Hondeveld et al. 1992, Epstein 1997). We observed microflagellates within the biofilm of fresh leaves but no quantification was made. The dominant macrograzers were snails with high abundances on both plants and the surface of the surrounding sediments. The activity of macrograzers on the leaves was also observed indirectly in the microscope as long paths lacking epiphytes. Grazing by snails on bacteria attached to seagrasses has been reported by van Montfrans et al. (1982) and Mazella \& Russo (1989).

Bacteria exhibited specific spatial and temporal distribution patterns, both on a microscale within the biofilm, on each leaf and between leaves of different ages. On older leaves, the bacterial cells closest to the plant surface formed a monolayer of large rods with a uniform size and immobilized with one end facing the plant surface. This bacterial bottom layer was covered with bacteria of different sizes and shapes appearing more randomly distributed in the biofilm matrix.

Newly emerged leaves were rapidly colonized by bacteria as shown by the high bacterial abundances at the base of these leaves. During summer the age of newly emerged leaves is less than $14 \mathrm{~d}$ (Wium-Andersen \& Borum 1984). Significant differences in bacterial spatial distribution were found on the leaves. On average, bacterial biomass increased by a factor of 1.4 from the leaf base to the leaf tip. Bacterial abundance, on the other hand, did not differ significantly between locations but exhibited a strong tendency to increase from base to tips on most sampling occasions. The increasing bacterial biomass with increasing distance from the leaf base is in agreement with the increase in bacterial abundance from leaf base to leaf tip on eelgrass previously found on 2 occasions during the summer (Kirchman et al. 1984). In comparison with our results, the differences between locations were larger and were explained by differences in exposure time caused by the growth pattern of eelgrass with growth from the base of the leaf.

Bacterial abundances between $1.7 \times 10^{5}$ and $4.0 \times$ $10^{7}$ cells $\mathrm{cm}^{-2}$ agree well with abundances of 2 to $8 \times$ $10^{6}$ cells $\mathrm{cm}^{-2}$ and $2 \times 10^{7}$ on green eelgrass leaves discovered by Kirchman et al. (1984) and Newell (1981), respectively. Bacterial abundance and biomass differed between leaves of different ages with a stepwise increase from the newest to the oldest leaf by a factor of 3.2 and 3.4, respectively. Increasing bacterial abundance between the newest and the oldest leaves has been described on the freshwater plant Ranunculus penicillatus (Hossell \& Baker 1979). Building of a biofilm takes time and the mature biofilm on old leaves is a result of many factors that may change over the exposure time. These factors include leaf structure, primary productivity, carbon/nutrient excretion rates, grazing, detachment or sloughing of cells, virus induced mortality, inhibitory substances produced by bacteria or algae, interactions with other organisms such as diatoms, etc.

Bacterial production also increased with leaf age and from leaf base to leaf tip. Since no significant differences in cell-specific bacterial growth rates were found either between locations on leaves or between leaves of different ages, the increase in bacterial production must mainly have been a result of the concurrent increase in bacterial abundance. This means that the growth rates remained constant and high even though bacterial biomass and biofilm thickness increased over time. The average difference in bacterial production between new and the oldest leaves was clearly larger than for bacterial abundance and biomass, indicating that the activity per cell may have been slightly, but not significantly, higher on old leaves. When bacterial specific growth rates were studied on a seasonal basis, patterns emerged that clearly differed from the tendency observed for bacterial abundance, biomass and production. Bacterial specific growth rates were highest during summer at the seasonal minima in bacterial abundance and biomass, indicating an important role of grazing and temperature during this period.

A recurrent problem in the use of radiolabelled nucleotides to determine bacterial production is achieving and determining the level of saturation and conversion factors. We found that leucine concentrations higher than $400 \mathrm{nM}$ were required to obtain saturation while thymidine appeared to be saturated at concentrations lower than $100 \mathrm{nM}$. At higher leucine concentrations (up to $1600 \mathrm{nM}$ ) and thymidine concentrations (up to $400 \mathrm{nM}$ ) no increases in incorporation rates were observed. Likewise, Thomaz \& Wetzel (1995) found that leucine concentrations above $400 \mathrm{nM}$ were required to saturate the biofilm on the freshwater macrophyte Juncus effusus. Experiments on freshwater macrophytes have shown that even higher leucine concentrations (up to $1200 \mathrm{nM}$ ) can be required in order to attain saturation (Theil-Nielsen unpubl. results). Such leucine concentrations are several orders of magnitude higher than those suggested for marine bacterioplankton (Simon \& Azam 1989). Thymidine incorporation appeared to be saturated at much lower concentrations and well below $100 \mathrm{nM}$, indicating different uptake kinetics for these molecules. Leucine and thymidine incorporation rates were significantly correlated but bacterial production based on leucine incorporation was on average 5.9 times higher than production estimates based on thymidine incorporation rates. We have chosen here the conversion factors most often used for bacterioplankton. These factors 
might not apply to biofilm bacteria, however, empirical evidence is not present to suggest other factors. When studied in detail, the ratio between bacterial production and molar uptake based on leucine and thymidine incorporation increased linearly by a factor of 2 as a function of increasing leaf age and by a factor of 1.8 from leaf base to leaf tip. This indicates a higher protein synthesis compared to DNA synthesis with increasing biofilm age and increasing bacterial abundance. The deviation cannot be explained by differences in bacterial cell size since no significant differences in cell size were found either between leaves of different age or between locations on leaves.

To summarize, eelgrass leaves were sites of highly active and dynamic bacterial communities. New leaves were rapidly colonized and with increasing age the leaves could host and support an increasing number of attached bacteria. Both bacterial biomass and activity exhibited distinct patterns of distribution with increasing bacterial abundance and production with increasing leaf age and from base to tip on individual leaves. Bacterial activity varied seasonally, largely following the changes in water temperature. ${ }^{14} \mathrm{C}$-leucine and ${ }^{3} \mathrm{H}$-thymidine incorporation rates were significantly correlated but the ratio between bacterial production based on leucine incorporation and thymidine incorporation increased with increasing leaf age and from leaf base to leaf tip. This suggests a higher protein synthesis compared to DNA synthesis with increasing biofilm age and increasing bacterial abundance. Estimates of bacterial biomass production from leucine and thymidine incorporation rates were very high compared to the standing stock of bacteria. We could estimate that close to $100 \%$ of the produced biomass was lost on a daily basis. Moreover, no differences in cell-specific bacterial activity were found as a function of leaf age or leaf location, altogether pointing at high bacterial loss rates and a close balance between production and loss of bacterial biomass. The very high cell-specific bacterial activity indicates a strong coupling between attached bacterial communities and plant primary production and excretion and shows that the biofilm on eelgrass is a favourable environment for bacterial growth.

Acknowledgements. Financial support from the Danish Environmental Research Programme is appreciated. We also thank Anne Jacobsen and Michael Opitz for technical assistance and Marcus Sundbom for help with the statistical evaluation. Valuable comments by John Stockner are much appreciated.

\section{LITERATURE CITED}

Aida W, Muraoka T, Seki H (1988) Effect of rapid oligotrophication by an aquatic treatment plant on the microbial community of a mesotrophic bog. 5. Attachment and growth kinetics of epibacteria. Water Air Soil Pollut $42\{3-4\}: 433-438$

Anonymous (1996) Overvågning af Roskilde Fjord, 1995 Vandmiljoovervågning nr.: 29. Roskilde Amt, Teknisk Forvaltning and Frederiksborg Amt, Teknik og miljø. ISBN 87-7781-115-1

Azam F, Fenchel T, Field JG, Grey JS, Meyer-Reil LA, Thingstad TF (1983) The ecological role of water-column microbes in the sea. Mar Ecol Prog Ser 10:257-263

Billen G, Servais P, Fontigny A (1988) Growth and mortality in bacterial population dynamics of aquatic environments. Arch Hydrobiol Beih Ergebn Limnol 31:173-183

Blum LK, Mills AL, Zieman JC, Zieman RT (1988) Abundance of bacteria and fungi in seagrass and mangrove detritus. Mar Ecol Prog Ser 42:73-78

Borum J, Geertz-Hansen O, Sand-Jensen K, Wium-Andersen $S$ (1990) Eutrophication: effects on marine plant communities. Report C3, NPo-research. Ministry of the Environment, Copenhagen

Brock TD, Madigan MT, Martinko JM, Parker J (1994) Biology of microorganisms. Prentice Hall, Englewood Cliffs, NJ

Ducklow HW, Carlson CA (1992) Oceanic bacterial production. Adv Microb Ecol 12:113-181

Epstein SS (1997) Microbial food webs in marine sediments. II. Seasonal changes in trophic interactions in a sandy tidal flat community. Microb Ecol 34:199-209

Fenchel T (1982) Ecology of heterotrophic microflagellates. IV. Quantitative occurrence and importance as consumers of bacteria. Mar Ecol Prog Ser 9:35-42

Fuhrman JA, Azam F (1980) Bacterioplankton secondary production estimates for coastal waters of British Columbia, Antarctica and California. Appl Environ Microbiol 39: $1085-1095$

Harlin MM (1980) Seagrass epiphytes. In: Phillips RC, McRoy CP (eds) Handbook of seagrass biology: an ecosystem perspective. Garland STPM Press, New York, p 117-151

Hondeveld BJ, Bak RPM, van Duyl FC (1992) Bacterivory by heterotrophic nanoflagellates in marine sediments measured by uptake of fluorescently labeled bacteria. Mar Ecol Prog Ser 89:63--71

Hossell JC, Baker JH (1979) Epiphytic bacteria on the freshwater plant Ranunculus penicillatus: enumeration, distribution and identification. Arch Hydrobiol 86(3): $322-337$

Kirchman D (1983) The production of bacteria attached to particles suspended in a freshwater pond. Limnol Oceanogr 28:858-872

Kirchman D (1993) Particulate detritus and bacteria in marine environments. In: Ford TE (ed) Aquatic microbiology. An ecological approach. Blackwell Scientific Publishers, Boston, p 321-341

Kirchman DL, Ducklow HW (1987) Trophic dynamics of particle-bound bacteria in pelagic ecosystems: a review. In Moriarty DJW, Pullin RSV (eds) Detritus and microbial ecology in aquaculture. International Center for Living Aquatic Resource Management, Manila, p 54-82

Kirchman DL, Mazzella L, Alberte RS, Mitchell R (1984) Epiphytic bacterial production on Zostera marina. Mar Ecol Prog Ser 15(1):117-123

Mazzella L, Russo GF (1989) Grazing effect of two Gibulla species (Mollusca, Archeogastropoda) on the epiphytic community of Posidonia oceanica leaves. Aquat Bot 35 : $357-373$

Moriarty DJW, Pollard PC (1982) Diel variation of bacterial productivity in seagrass (Zostera capricorni) beds mea- 
sured by rate of thymidine incorporation into DNA. Mar Biol 72:165-173

Morris DP, Lewis WM Jr (1992) Nutrient limitation of bacterioplankton growth in Lake Dillon, Colorado. Limnol Oceanogr 37(6):1179-1192

Neckles HA, Koepfler ET, Haas LW, Wetzel RL, Orth RJ (1994) Dynamics of epiphytic photoautotrophs and heterotrophs in Zostera marina (eelgrass) microcosms: responses to nutrient enrichment and grazing. Estuaries 17(3): $597-605$

Newell SY (1981) Fungi and bacteria in or on leaves of eelgrass (Zostera marina L.) from Chesapeake Bay. Appl Environ Microbiol 41:1219-1224

Novak R (1984) A study in ultra-ecology: microorganisms on the seagrass Posidonia oceanica (L.) Delile. PSZN I: Mar Ecol 5:143-190

Penhale PA, Thayer GW (1980) Uptake and transfer of carbon and phosphorus by eelgrass (Zostera marina L.) and its epiphytes. J Exp Mar Biol Ecol 42:114-123

Porter KG, Feig YS (1980) The use of DAPI for identifying and counting aquatic microflora. Limnol Oceanogr 25:943-948

Editonal responsibility: Otto Kinne (Editor),

Oldendorf/Luhe, Germany
Simon M, Azam F (1989) Protein content and protein synthesis rates of planktonic marine bacteria. Mar Ecol Prog Ser $51: 201-213$

Theil-Nielsen J, Sondergaard M (1998) Bacterial carbon bjomass calculated from biovolumes. Arch Hydrobiol 141:195-207

Thomaz SM, Wetzel RG (1995) [3H]Leucine incorporation methodology to estimate epiphytic bacterial biomass production. Microb Ecol 29:63-70

van Montfrans J, Orth RJ, Vay SA (1982) Preliminary studies of grazing by Bittium varium on eelgrass periphyton. Aquat Bot 14:78-89

Wetzel RG, Manny BA (1972) Secretion of dissolved organic carbon and nitrogen by aquatic macrophytes. Verh Int Verein Limnol 18:162-170

Wium-Andersen S, Borum J (1984) Biomass variation and autotrophic production of an epiphyte macrophyte community in a coastal Danish area: I Eelgrass (Zostera marina L.) biomass and net production. Ophelia 23:33-46

Ytow N, Seki H (1996) Microcolonization mechanism of attached bacteria in a natural water column. $J$ Oceanogr 52(2):207-219

Submitted: August 3, 1998; Accepted: December 2, 1998

Proofs received from author(s): March 25, 1999 